\title{
Clinical characteristics and laboratory findings of COVID-19 in Istanbul
}

\author{
Istanbul'da COVID-19'un klinik özellikleri ve laboratuvar bulgular
}

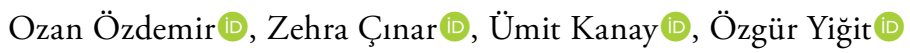 \\ Department of Otolaryngology, University of Health Sciences, Istanbul Training and Research Hospital, Istanbul, Turkey
}

\begin{abstract}
Objectives: The aim of this study is to evaluate the ear, nose and throat (ENT) symptoms and laboratory findings of Coronavirus disease 2019 (COVID-19) in Istanbul.

Patients and Methods: The single-center study included 121 COVID-19 patients (55 males, 66 females; mean age 59.1 \pm 11.6 years; range, 19 to 92 years) followed up between March 15, 2020 and May 15, 2020 at the COVID-19 ward Istanbul Training and Research Hospital in Turkey. The patients were confirmed for COVID-19 with reverse transcriptasepolymerase chain reaction (RT-PCR) and asked to fill in the questionnaire about ENT symptoms. Their clinical data were gathered by reviewing electronic medical records.
\end{abstract}

Results: Common symptoms included fever (74.3\%, $\mathrm{n}=90)$, fatigue $(69.4 \%, \mathrm{n}=84)$, dry cough $(68.5 \%, \mathrm{n}=83)$ and dyspnea $(61.9 \%, \mathrm{n}=75)$. Hypertension was the most common comorbidity (50.4\%), followed by diabetes mellitus (33.1\%). According to lung imaging, $90 \%$ of patients showed ground-glass opacity. Compared with non-severely ill patients, severely ill patients were older (mean age $65.4 \pm 12.3$ vs. $57.2 \pm 10.8$ years, $\mathrm{p}<0.05$ ), had a higher proportion of hypertension $(43.4 \%$ vs. $72.4 \%, \mathrm{p}=0.012)$ and fever. One (3.4\%) of the 29 severely ill patients received invasive mechanical ventilation.

Conclusion: COVID-19 patients sometimes present without fever and may not have abnormal radiologic findings. Older patients or patients with comorbidities are more likely to have a severe condition. The use of glucocorticoids in treatment is still controversial and more clinical studies are needed.

Keywords: Coronavirus disease 2019, COVID-19, SARS-CoV-2.
$\ddot{O} Z$

Amaç: Bu çalışmada 2019 Koronavirüs hastalığının (COVID-19) kulak, burun ve boğaz (KBB) semptomları ve laboratuvar bulguları değerlendirildi.

Hastalar ve Yöntemler: İstanbul Eğitim ve Araştırma Hastanesi COVID-19 servisinde 15 Mart 2020-15 Mayıs 2020 tarihleri arasında takip edilen 121 COVID-19 hastası (55 erkek, 66 kadın; ort. yaş 59.1 \pm 11.6 yıl; dağılım, 19-92 yıl) tek merkezli çalışmaya dahil edildi. Hastalar, COVID-19 pozitifliği için revers transkriptaz polimeraz zincir reaksiyonu (RT-PCR) ile test edildi ve KBB semptomları hakkında anketi doldurmaları istendi. Hastaların klinik verileri elektronik tıbbi kayıtları gözden geçirilerek toplandı.

Bulgular: Yaygın semptomlar arasında ateş (\%74.3, n=90), yorgunluk (\%69.4, n=84), kuru öksürük $(\% 68.5, n=83)$ ve nefes darlığı (\%61.9, n=75) vardı. En yaygın komorbidite hipertansiyondu (\%50.4), onu diabetes mellitus (\%33.1) izledi. Akciğer görüntülemesine göre hastaların \%90'^ buzlu cam opasitesi gösterdi. Ağır olmayan hastalarla karşılaştırıldığında, ağır hastalar daha yaşlıydı (ort. yaş $65.4 \pm 12.3$ yıla karşın $57.2 \pm 10.8$ y1l, $\mathrm{p}<0.05)$, hastalarda daha yüksek oranda hipertansiyon (\%43.4'e karşın \%72.4, $\mathrm{p}=0.012$ ) ve ateş vardı. Ağır hasta olarak takip edilen 29 hastadan biri (\%3.4) invazif mekanik ventilasyona ihtiyaç duydu.

Sonuç: COVID-19 hastaları bazen ateşsiz başvurabilir ve anormal radyolojik bulgulara sahip olmayabilir. Yaşlı hastalar veya komorbiditeleri olan hastaların hastalığının şiddetli seyretme ihtimali daha fazladır. Tedavide glukokortikoidlerin kullanımı hala tartışmalıdır ve daha fazla klinik çalışmaya ihtiyaç vardır.

Anahtar sözcükler: Koronavirus hastalığı 2019, COVID-19, SARS-CoV-2

Received: February 08, 2021 Accepted: March 29, 2021 Published online: August 13, 2021

Correspondence: Ozan Özdemir, MD. SBÜ İstanbul Eğitim ve Araştırma Hastanesi, Kulak Burun Boğaz Kliniği, 34098 Fatih, İstanbul, Türkiye. e-mail: opdrozanozdemir@gmail.com 
In December 2019, an acute respiratory illness was identified in Wuhan. ${ }^{[1,2]}$ The disease has spread rapidly around the world. The new type of coronavirus was seen in samples of airway epithelial cells taken from patients. ${ }^{[3]}$ After a month, it was named severe acute respiratory syndrome coronavirus 2 (SARS-CoV-2). ${ }^{[4]}$ There is evidence of rapid human-to-human transmission. ${ }^{[5,6]}$

In March, 2020, the World Health Organization declared this disease a pandemic. ${ }^{[7]}$ Approximately 50 million confirmed cases have been reported globally, including an estimated 1.25 million deaths in 150 countries. Despite being the country where the pandemic started, China is currently among the countries with the lowest number of cases in the world.
America is currently the country with the highest number of cases with more than 10 million, followed by India with more than 8 million cases. Although the number of daily cases had decreased for a while with the measures taken by the governments, a second wave of increase has started to be felt, particularly in Europe.

In Turkey, the Coronavirus disease 2019 (COVID-19) outbreak first started to appear in early February 2020. The disease initially appeared as a pneumonia of unknown cause with a need for intensive care in postoperative young patients. Although initially there were some difficulties in achieving consensus on follow-up and treatment, our clinical approach has evolved. Although the first wave was successfully

\begin{tabular}{|c|c|c|c|c|c|c|c|c|c|}
\hline \multicolumn{10}{|c|}{$\begin{array}{c}\text { Table } 1 \\
\text { Baseline characteristics of patients with COVID-19 }\end{array}$} \\
\hline & \multicolumn{4}{|c|}{ Non-severely ill patients ( $n=92)$} & \multicolumn{4}{|c|}{ Severely ill patients $(\mathrm{n}=29)$} & \multirow[b]{2}{*}{$p$} \\
\hline & $\mathrm{n}$ & $\%$ & Mean \pm SD & Median & $\mathrm{n}$ & $\%$ & Mean \pm SD & Median & \\
\hline Age (year) & & & $57.2 \pm 10.8$ & 58.0 & & & $65.4 \pm 12.3$ & 66.0 & $0.000^{*}$ \\
\hline Sex & & & & & & & & & $0.102 \dagger$ \\
\hline Female & 54 & 58.7 & & & 12 & 41.4 & & & \\
\hline Male & 38 & 41.3 & & & 17 & 58.6 & & & \\
\hline Smoking history & & & & & & & & & $0.928 \dagger$ \\
\hline Never & 71 & 77.2 & & & 23 & 79.3 & & & \\
\hline Quit & 12 & 13.0 & & & 3 & 10.3 & & & \\
\hline User & 9 & 9.8 & & & 3 & 10.3 & & & \\
\hline Comorbidities & & & & & & & & & $0.309 \dagger$ \\
\hline$(-)$ & 28 & 30.4 & & & 6 & 20.7 & & & \\
\hline$(+)$ & 64 & 69.6 & & & 23 & 79.3 & & & \\
\hline Hypertension & 40 & 43.4 & & & 21 & 72.4 & & & $0.012 \dagger$ \\
\hline Diabetes mellitus & 27 & 29.3 & & & 13 & 44.8 & & & $0.187 \dagger$ \\
\hline Chest CT abnormaliti & & & & & & & & & \\
\hline$(-)$ & 2 & 2.2 & & & 3 & 10.3 & & & \\
\hline$(+)$ & 90 & 97.8 & & & 26 & 89.7 & & & \\
\hline Ground-glass opacity & 86 & 93.5 & & & 23 & 79.3 & & & $0.061 \dagger$ \\
\hline Pneumonia & 4 & 4.3 & & & 3 & 10.4 & & & $0.453 \dagger$ \\
\hline Complications & & & & & & & & & $0.173 \dagger$ \\
\hline$(-)$ & 82 & 89.1 & & & 23 & 79.3 & & & \\
\hline$(+)$ & 10 & 10.9 & & & 6 & 20.7 & & & \\
\hline Intensive care unit & & & & & & & & & $0.042 \dagger$ \\
\hline$(-)$ & 91 & 98.9 & & & 26 & 89.7 & & & \\
\hline$(+)$ & 1 & 1.1 & & & 3 & 10.3 & & & \\
\hline Death & & & & & & & & & $0.240 \dagger$ \\
\hline$(-)$ & 92 & 100.0 & & & 28 & 96.6 & & & \\
\hline$(+)$ & 0 & 0.0 & & & 1 & 3.4 & & & \\
\hline
\end{tabular}


overcome with the curfews imposed by the government, a larger second wave is expected today.

In this study, we analyzed the ear, nose and throat (ENT) symptoms and laboratory findings of polymerase chain reaction (PCR)-confirmed COVID-19 patients. The purpose of this case series was to compare the data of our patients with those of other countries.

\section{PATIENTS AND METHODS}

All patients were admitted to the hospital without selectivity and confirmed with PCR. All patients were treated in single patient rooms, and the clinical outcomes were followed up to May 15, 2020. The study included 121 patients (55 males, 66 females; mean age $59.1 \pm 11.6$ years; range, 19 to 92 years) with confirmed cases of COVID-19 who did not need to be admitted to the intensive care unit (ICU) during the follow-up. Four patients were admitted to the ICU during our follow-up period and three of them were discharged. Only one patient died. As of June 2, all patients had been discharged. Data on blood tests were collected by reviewing electronic medical records. The patients answered the questionnaire about the 16 most common ENT symptoms and were asked to rank their symptoms from 0 to 5 according to their severity. Demographic data of the patients were recorded, including age, sex, underlying diseases, symptoms, signs, laboratory findings, chest computed tomography (CT) scans and treatment measures (antiviral therapy, antibiotherapy). Cases were diagnosed based on the World Health Organization guidelines ${ }^{[8]} \mathrm{A}$ confirmed case was defined as a positive result to reverse transcriptase (RT)-PCR assay with nasal and pharyngeal swab specimens. ${ }^{[9]}$ The patients were divided into two groups as severely ill and non-severely ill patients. In the treatment of the patients, national treatment protocols inspired by the SARS-CoV-2-Related Pneumonia Diagnosis and Treatment guidelines were followed. ${ }^{[10]}$ Severe condition was defined as transcutaneous oxygen saturation $\left(\mathrm{SaO}_{2}\right)$ $\leq 93 \%$ in a resting state. ${ }^{[11]}$ The study was approved by the Local Ethics Committee (No.2446/12.06.2020). The study was conducted in accordance with the principles of the Declaration of Helsinki.

\section{Statistical analysis}

Statistical analysis was performed using the IBM SPSS version 26.0 software (IBM Corp., Armonk, NY, USA). Descriptive data were expressed in mean \pm standard deviation, median (min-max) or frequency and number. The distribution of variables was assessed with the Kolmogorov-Smirnov test. Mann-Whitney $\mathrm{U}$ test was used in the analysis of quantitative data, and

\begin{tabular}{|c|c|c|c|c|c|}
\hline \multicolumn{6}{|c|}{$\begin{array}{l}\text { Table } 2 \\
\text { Signs and symptoms of patients with COVID-19 }\end{array}$} \\
\hline & \multicolumn{2}{|c|}{ Non-severely ill patients $(\mathrm{n}=92)$} & \multicolumn{2}{|c|}{ Severely ill patients $(n=29)$} & \multirow[b]{2}{*}{$p^{*}$} \\
\hline & Mean \pm SD & Median & Mean \pm SD & Median & \\
\hline Nasal congestion & $0.5 \pm 1.1$ & 0.0 & $0.6 \pm 1.2$ & 0.0 & 0.976 \\
\hline Rhinorrhea & $0.3 \pm 0.9$ & 0.0 & $0.4 \pm 1.1$ & 0.0 & 0.682 \\
\hline Conjunctival congestion & $0.1 \pm 0.6$ & 0.0 & $0.2 \pm 0.8$ & 0.0 & 0.747 \\
\hline Postnasal drip & $0.2 \pm 0.8$ & 0.0 & $0.3 \pm 0.8$ & 0.0 & 0.633 \\
\hline Dry cough & $2.0 \pm 1.5$ & 2.0 & $1.7 \pm 1.5$ & 2.0 & 0.363 \\
\hline Sputum production & $0.7 \pm 1.1$ & 0.0 & $0.6 \pm 1.2$ & 0.0 & 0.635 \\
\hline Fatigue & $2.3 \pm 1.9$ & 2.5 & $2.5 \pm 1.6$ & 3.0 & 0.634 \\
\hline Face pain/heaviness & $0.1 \pm 0.6$ & 0.0 & $0.1 \pm 0.6$ & 0.0 & 0.833 \\
\hline Ear pain & $0.2 \pm 0.7$ & 0.0 & $0.2 \pm 0.7$ & 0.0 & 0.505 \\
\hline Olfactory dysfunctions & $1.2 \pm 1.7$ & 0.0 & $0.7 \pm 1.4$ & 0.0 & 0.143 \\
\hline Gustatory dysfunctions & $1.4 \pm 1.8$ & 0.0 & $1.0 \pm 1.5$ & 0.0 & 0.287 \\
\hline Headache & $1.0 \pm 1.5$ & 0.0 & $0.4 \pm 0.9$ & 0.0 & 0.063 \\
\hline Sore throat & $0.7 \pm 1.3$ & 0.0 & $0.3 \pm 0.9$ & 0.0 & 0.114 \\
\hline Nausea/vomiting & $0.5 \pm 1.0$ & 0.0 & $0.6 \pm 1.1$ & 0.0 & 0.542 \\
\hline Dyspnea & $1.6 \pm 1.5$ & 2.0 & $1.9 \pm 1.6$ & 2.0 & 0.347 \\
\hline Fever & $36.9 \pm 0.9$ & 36.8 & $37.6 \pm 0.9$ & 37.3 & 0.001 \\
\hline
\end{tabular}


chi-square test and Fisher's exact test were used in the analysis of qualitative independent data. A two-tailed $p$ value of $<0.05$ was considered statistically significant.

\section{RESULTS}

The characteristics of the patients included in the study were summarized in Table 1 . The need for intensive care was found to be significantly higher in severely ill patients. The most common comorbidity was hypertension $(50.4 \%, \mathrm{n}=61)$, followed by diabetes mellitus (33.1\%, $\mathrm{n}=40)$. The average age of severely ill patients was older than non-severely ill patients (mean age $65.4 \pm 12.3$ vs. $57.2 \pm 10.8$ years, $\mathrm{p}<0.05$ ). According to CT, 90.1\% ( $\mathrm{n}=109)$ of patients showed ground-glass opacity and $5.7 \%(n=7)$ of patients showed pneumonia. Finally, 4.2\% $(n=5)$ of patients showed no abnormal results.
The differences in signs and symptoms of patients were not numerous (Table 2). Fever $(74.3 \%, \mathrm{n}=90)$, fatigue $(69.4 \%, n=84)$, dry cough $(68.5 \%, n=83)$ and dyspnea $(61.9 \%, n=75)$ were the most common symptoms of illness. Less common symptoms were conjunctival congestion, face pain, ear pain and postnasal drip. Severely ill patients were more likely to report fever $(\mathrm{p}<0.001)$. Other symptoms were not significant between the two groups.

The differences in laboratory findings between severely ill patients and non-severely ill patients were shown in Table 3. Severely ill patients had higher levels of C-reactive protein, aspartate aminotransferase, lactate dehydrogenase, and serum creatinine. However, absolute lymphocyte count, albumin and subcutaneous oxygen saturation $\left(\mathrm{SaO}_{2}\right)$ were lower.

The need for intensive care was significantly higher in severely ill patients $(10.3 \%$ vs. $1.1 \%, \mathrm{p}<0.05)$ but

\begin{tabular}{|c|c|c|c|c|c|}
\hline \multicolumn{6}{|c|}{$\begin{array}{l}\text { Table } 3 \\
\text { gs of patients with COVID-19 }\end{array}$} \\
\hline & \multicolumn{2}{|c|}{ Non-severely ill patients $(\mathrm{n}=92)$} & \multicolumn{2}{|c|}{ Severely ill patients $(\mathrm{n}=29)$} & \multirow[b]{2}{*}{$p^{*}$} \\
\hline & Mean \pm SD & Median & Mean \pm SD & Median & \\
\hline Systolic blood pressure & $132.2 \pm 14.9$ & 130.0 & $134.8 \pm 19.5$ & 130.0 & 0.837 \\
\hline Diastolic blood pressure & $82.6 \pm 8.8$ & 80.0 & $82.0 \pm 9.6$ & 85.0 & 0.909 \\
\hline $\mathrm{WBC}\left(\times 10^{9} / \mathrm{L}\right)$ & $6.1 \pm 3.0$ & 5.5 & $7.3 \pm 2.8$ & 6.5 & 0.024 \\
\hline Lymphocyte count $\left(\mathrm{x} 10^{9} / \mathrm{L}\right)$ & $1.6 \pm 0.8$ & 1.5 & $1.2 \pm 0.4$ & 1.0 & 0.002 \\
\hline Platelet $\left(\times 10^{9} / \mathrm{L}\right)$ & $203.8 \pm 74.4$ & 193.0 & $196.8 \pm 66.5$ & 202.0 & 0.954 \\
\hline CRP (mg/L) & $42.6 \pm 49.3$ & 24.0 & $72.4 \pm 56.8$ & 79.0 & 0.008 \\
\hline Albumin $(\mathrm{g} / \mathrm{L})$ & $89.1 \pm 458.2$ & 40.9 & $38.2 \pm 7.8$ & 38.4 & 0.003 \\
\hline $\mathrm{CK}(\mu \mathrm{g} / \mathrm{L})$ & $136.5 \pm 235.2$ & 82.5 & $142.5 \pm 170.7$ & 105.0 & 0.411 \\
\hline $\operatorname{AST}(\mathrm{U} / \mathrm{L})$ & $32.4 \pm 20.0$ & 27.0 & $40.9 \pm 23.4$ & 37.0 & 0.031 \\
\hline $\operatorname{ALT}(\mathrm{U} / \mathrm{L})$ & $33.2 \pm 41.5$ & 22.0 & $30.6 \pm 25.1$ & 23.0 & 0.813 \\
\hline $\operatorname{ALP}(\mathrm{U} / \mathrm{L})$ & $98.1 \pm 49.2$ & 88.0 & $96.8 \pm 32.6$ & 98.0 & 0.475 \\
\hline $\mathrm{LDH}(\mathrm{U} / \mathrm{L})$ & $264.9 \pm 105.3$ & 248.0 & $334.0 \pm 137.3$ & 287.0 & 0.002 \\
\hline $\mathrm{TBil}(\mu \mathrm{mol} / \mathrm{L})$ & $0.7 \pm 0.2$ & 0.7 & $0.8 \pm 0.2$ & 0.7 & 0.520 \\
\hline $\mathrm{BUN}(\mathrm{mmol} / \mathrm{L})$ & $34.0 \pm 22.9$ & 29.1 & $56.7 \pm 56.6$ & 31.1 & 0.144 \\
\hline $\mathrm{SCr}(\mu \mathrm{mol} / \mathrm{L})$ & $0.9 \pm 0.8$ & 0.8 & $1.6 \pm 1.8$ & 0.9 & 0.016 \\
\hline $\operatorname{APTT}(\mathrm{s})$ & $25.8 \pm 4.2$ & 26.0 & $27.0 \pm 3.6$ & 27.5 & 0.220 \\
\hline $\mathrm{D}$-dimer $(\mathrm{mg} / \mathrm{L})$ & $2.6 \pm 8.6$ & 0.6 & $2.7 \pm 6.1$ & 0.7 & 0.443 \\
\hline Sodium (mmol/L) & $135.8 \pm 11.3$ & 137.0 & $136.3 \pm 3.5$ & 137.0 & 0.341 \\
\hline Potassium (mmol/L) & $8.3 \pm 41.4$ & 3.9 & $32.7 \pm 107.0$ & 4.0 & 0.426 \\
\hline Chloride (mmol/L) & $109.6 \pm 93.8$ & 100.0 & $104.0 \pm 18.1$ & 100.0 & 0.582 \\
\hline $\mathrm{SaO}_{2}$ & $96.1 \pm 1.5$ & 96.0 & $91.0 \pm 2.5$ & 92.0 & 0.000 \\
\hline
\end{tabular}

SD: Standard deviation; * Mann-Whitney U test; WBC: White blood cell count; CRP: C-reactive protein; CK: Creatine kinase; AST: Aspartate aminotransferase; ALT: Alanine aminotransferase; ALP: Alkaline phosphatase; LDH: Lactate dehydrogenase; TBil: Total bilirubin; BUN: Blood urea nitrogen; SCr: Serum creatinine; APTT: Activated partial thromboplastin time; $\mathrm{SaO} 2$ : Transcutaneous oxygen saturation. 
there were no significant differences in complications between the two groups.

Most patients received hydroxychloroquine and azithromycin therapy $(80.1 \%, \mathrm{n}=97)$. Many received oral antiviral therapy (oseltamivir/favipiravir, 73.5\%, $\mathrm{n}=89$ ) and antibiotherapy (ceftriaxone therapy, 23.1\%, $\mathrm{n}=28$; piperacillin/tazobactam therapy, $17.3 \%, \mathrm{n}=21$; moxifloxacin therapy, $4.9 \%, \mathrm{n}=6$ ).

\section{DISCUSSION}

Despite the need for effective strategies to control the spread of epidemics, there are wide differences in social development, economic growth and political capacities around the world. Estimating the epidemic prevalence is crucial for the allocation of medical resources and even for the national economic development of countries. Although most countries are trying to formulate their preparations to deal with the COVID-19 outbreak, reaching a common worldwide consensus will be crucial.

Many regions of the world have a low Human Development Index, such as in many parts of Latin America, Asia and Africa. In some countries, such as Syria and Venezuela, where humanitarian crises have been experienced since 2019, the impact of the COVID-19 outbreak will be more devastating than in the more developed economies. ${ }^{[12]}$

In recent studies, evaluations made by Autoregressive Integrated Moving Average (ARIMA) time series models showed that the prevalence of COVID-19 was the highest in the three most visited countries in Europe: Italy, Spain and France. ${ }^{[13]}$ Thus, a high influx of tourists may also increase the risk.

This report is one of the largest single-center case series of patients with COVID-19 in Istanbul. In a worldwide multicenter study, the male sex was more commonly ill in all databases except for France. ${ }^{[14]} \mathrm{We}$ also had similar results in our study.

In concert with recent studies, we found that the severely ill patients were older and had comorbidities such as hypertension. ${ }^{[15,16]}$ As with previous studies there was no difference between sexes in our study. ${ }^{[17]}$ Contrary to our results, there are studies in which the most common comorbidity is asthma ${ }^{[14,18]}$ (Spain, France, Korea, US and UK), followed by obesity ${ }^{[14]}$ (Spain, France, Korea and US).

Consistent with previous studies, fever, fatigue and dry cough were the most common symptoms in our study. ${ }^{[14-16,18]}$ However non-severely ill patients sometimes presented without fever. In some countries, dyspnea, anosmia and gastrointestinal symptoms were more common in COVID-19 than influenza. ${ }^{[14]}$

Consistent with previous studies, our study also found that the absolute value of lymphocytes in most patients decreased. ${ }^{[17,19]}$ Severely ill patients had higher levels of C-reactive protein, aspartate aminotransferase, lactate dehydrogenase, and serum creatinine. These results show that the pathogenicity of SARS-CoV-2 infection may be associated with cellular immunodeficiency, myocardial and hepatic injury. ${ }^{[17]}$ Our study found that severely ill patients often have pneumonia lesions on the chest CT. This suggests that pneumonia is one of the risk factors for the severe course of the disease.

Most of the patients in this study received hydroxychloroquine (98.3\%, $\mathrm{n}=119)$, combined hydroxychloroquine and azithromycin therapy $(80.1 \%$, $\mathrm{n}=97$ ), antiviral therapy (oseltamivir/favipiravir, $73.5 \%, \mathrm{n}=89)$, ceftriaxone therapy $(23.1 \%, \mathrm{n}=28)$, piperacillin/tazobactam therapy $(17.3 \%, \mathrm{n}=21)$ and moxifloxacin therapy $(4.9 \%, n=6)$. Contrary to our results, antiviral drugs were not used in $85 \%$ of the patients in UK. ${ }^{[18]}$ Since lymphopenia is more common in severely ill patients, these patients were given more intravenous antibiotics to increase the anti-infection defense reaction. ${ }^{[19]}$

The use of glucocorticoids is still controversial, so only 1 of 121 patients we included in our study were treated with systemic glucocorticoids. According to WHO interim guidance, glucocorticoid should not be routinely given systemically. ${ }^{[8]}$ Another study showed that no benefit was observed from glucocorticoid supplementation in COVID-19. ${ }^{[20]}$

Our study has some notable limitations. Some cases had incomplete documentation of laboratory testing. Therefore, some laboratory tests were excluded. Secondly, only four critically ill patients were monitored in our study. Thus, our research may not be applicable to critically ill patients.

In conclusion, patients sometimes presented without fever and did not have abnormal radiologic findings, and older patients or patients with comorbidities were more likely to have a severe condition. Different sociological, economic and political situations in different parts of the world explain the epidemiology of the disease and differences in clinical management. The world needs to cooperate more in the fight against the pandemic.

\section{Declaration of conflicting interests}

The authors declared no conflicts of interest with respect to the authorship and/or publication of this article. 


\section{Funding}

The authors received no financial support for the research and/or authorship of this article.

\section{REFERENCES}

1. Hui DS, I Azhar E, Madani TA, Ntoumi F, Kock R, Dar $\mathrm{O}$, et al. The continuing 2019-nCoV epidemic threat of novel coronaviruses to global health - The latest 2019 novel coronavirus outbreak in Wuhan, China. Int J Infect Dis 2020;91:264-6.

2. Report of novel coronavirus-infected pneumonia in China. Wuhan Municipal Health Commission. 2020. Available at: https://wjw.wuhan.gov.cn/ front/web/ showDetail/2020012009077

3. Zhu N, Zhang D, Wang W, Li X, Yang B, Song J, et al. A novel coronavirus from patients with pneumonia in China, 2019. N Engl J Med 2020;382:727-33.

4. Coronaviridae Study Group of the International Committee on Taxonomy of Viruses. The species Severe acute respiratory syndrome-related coronavirus: Classifying 2019- $\mathrm{nCoV}$ and naming it SARS-CoV-2. Nat Microbiol 2020;5:536-44.

5. Chan JF, Yuan S, Kok KH, To KK, Chu H, Yang J, et al. A familial cluster of pneumonia associated with the 2019 novel coronavirus indicating person-to-person transmission: A study of a family cluster. Lancet 2020;395:514-23.

6. Wu JT, Leung K, Leung GM. Nowcasting and forecasting the potential domestic and international spread of the 2019$\mathrm{nCoV}$ outbreak originating in Wuhan, China: A modelling study. Lancet 2020;395:689-97.

7. World Health Organization. Coronavirus disease 2019 (COVID-19): Situation report, 51. World Health Organization 2020.

8. Clinical management of severe acute respiratory infection when COVID-19 is suspected. World Health Organization. Available at: https://apps.who.int/iris/rest/ bitstreams/1279870/retrieve

9. Huang C, Wang Y, Li X, Ren L, Zhao J, Hu Y, et al. Clinical features of patients infected with 2019 novel coronavirus in Wuhan, China. Lancet 2020;395:497-506.

10. Diagnosis and Treatment of Pneumonia Caused by SARSCOV-2 (version 7). National Health Commission of the
People's Republic of China. https:/www.nhc.gov.cn/xcs/ zhengcwj/202003/46c92 94a7dfe4cef80dc7f5912eb1989/ files/ce3e6945832a438eaae4 15350a8ce964.pdf

11. Singer M, Deutschman CS, Seymour CW, Shankar-Hari M, Annane D, Bauer M, et al. The Third International Consensus Definitions for Sepsis and Septic Shock (Sepsis-3). JAMA 2016;315:801-10.

12. Rodriguez-Morales AJ, Gallego V, Escalera-Antezana JP, Méndez CA, Zambrano LI, Franco-Paredes C, et al. COVID-19 in Latin America: The implications of the first confirmed case in Brazil. Travel Med Infect Dis 2020;35:101613.

13. Ceylan Z. Estimation of COVID-19 prevalence in Italy, Spain, and France. Sci Total Environ 2020;729:138817.

14. Duarte-Salles T, Vizcaya D, Pistillo A, Casajust P, Sena AG, Lai LYH, et al. Baseline characteristics, management, and outcomes of 55,270 children and adolescents diagnosed with COVID-19 and 1,952,693 with influenza in France, Germany, Spain, South Korea and the United States: An international network cohort study. medRxiv 2020.

15. Guan WJ, Ni ZY, Hu Y, Liang WH, Ou CQ, He JX et al. Clinical characteristics of coronavirus disease 2019 in China. N Engl J Med 2020;382:1708-20.

16. Chen Q, Zheng Z, Zhang C, Zhang X, Wu H, Wang J, et al. Clinical characteristics of 145 patients with corona virus disease 2019 (COVID-19) in Taizhou, Zhejiang, China. Infection 2020;48:543-51.

17. Wang D, Hu B, Hu C, Zhu F, Liu X, Zhang J, et al. Clinical characteristics of 138 hospitalized patients with 2019 novel coronavirus-infected pneumonia in Wuhan, China. JAMA 2020;323:1061-9.

18. Swann OV, Holden KA, Turtle L, Pollock L, Fairfield CJ, Drake TM, et al. Clinical characteristics of children and young people admitted to hospital with covid-19 in United Kingdom: Prospective multicentre observational cohort study. BMJ 2020;370:m3249.

19. Chen N, Zhou M, Dong X, Qu J, Gong F, Han Y, et al. Epidemiological and clinical characteristics of 99 cases of 2019 novel coronavirus pneumonia in Wuhan, China: A descriptive study. Lancet 2020;395:507-13.

20. Russell CD, Millar JE, Baillie JK. Clinical evidence does not support corticosteroid treatment for 2019-nCoV lung injury. Lancet 2020;395:473-5. 